\title{
A Study on Critical Factors affecting the Quality Performance of Construction
}

\author{
W. Femina \\ Department of Civil Engineering \\ Veltech Multitech DR RR DR SR Engineering College, Chennai, Tamilnadu, India \\ D.Jackson \\ Department of Civil Engineering \\ Chandy College Of Engineering, Tuticorin, Tamilnadu, India \\ B.Rajkumar \\ Department Of Civil Engineering \\ Jerusalem College Of Engineering, Chennai, Tamilnadu, India
}

\begin{abstract}
Quality measurement is the trigger for quality improvement. The things which cannot be measured cannot be improved. The real scope of quality improvement in construction projects is the difficulty and may be lack of quality measurement methods. The construction industry plays a vital role in the economy. The need for achieving quality of the finished product in the building construction is very important. Quality is an essential element for sustainability and customer satisfaction. Quality in its simplest form can be defined as 'meeting the customer expectations', or 'compliance with customer specification'. A total of 40 questionnaires were distributed to 2 key groups of project participants; namely consultants and contractors. This study is intended to provide clients, project managers, designers, and contractors with necessary information needed to better manage the quality of a construction building projects by identifying the factors that affect process quality of construction projects and to rank them by degree of importance. Certain construction companies identified and a questionnaire survey was carried out there. Then the data's from the company was collected. The ranking of the factors is done by using Relative Importance Index. Using that data's the major factors that affecting the quality have been identified. Then from the results suitable suggestions was given to the companies for improving their product quality.
\end{abstract}

Keywords - Quality, Customer Satisfaction, Sustainability, Relative Importance Index.

\section{INTRODUCTION}

Quality has become a very popular subject in recent years due to conceptual changes in the industry. Quality and quality systems are topics which have been receiving increasing attention worldwide. The product in any industry should be manufactured to a required standard, one that provides customer satisfaction and value for money. The need for achieving quality of the finished product in the building construction is very important. The high cost of buildings makes it necessary to ensure quality of the finished product.

Quality is an essential element for sustainability and customer satisfaction. For a user, quality is nothing but satisfaction with the appearance, performance, and reliability of the project for a given price range. . In the project management, the schedule, cost and quality achievement is also referred to as the iron triangle. Out of these three aspects, the achievement of schedule and cost compliances of the project management is attending the most of the time. For project owners, there are many benefits to working only with contractors having formal quality management protocols. Poor quality performance that results in increased rework and has significant impacts on cost and schedule is among the major defects experienced in construction projects. This will be a key component of any organization move towards achieving best practice in order to overcome the quality performance problem in the construction projects.

\section{OBJECTIVES}

The objectives of the present study are as given below: 
To identify various factors affecting the quality performance of construction projects and to rank them by degree of importance.

$>$ To suggest ways to improve the quality performance of construction projects.

\section{METHODOLOGY OF STUDY}

From literature review and past studies, it was obtained that there were different directions and methodologies used in order to achieve the required target, goals and objectives. Some of previous studies concentrated on one or two directions such as cost, time or quality performance. Some of studies deal with different aspects related to performance such as information technology. The methodology for this study is shown in figure 1

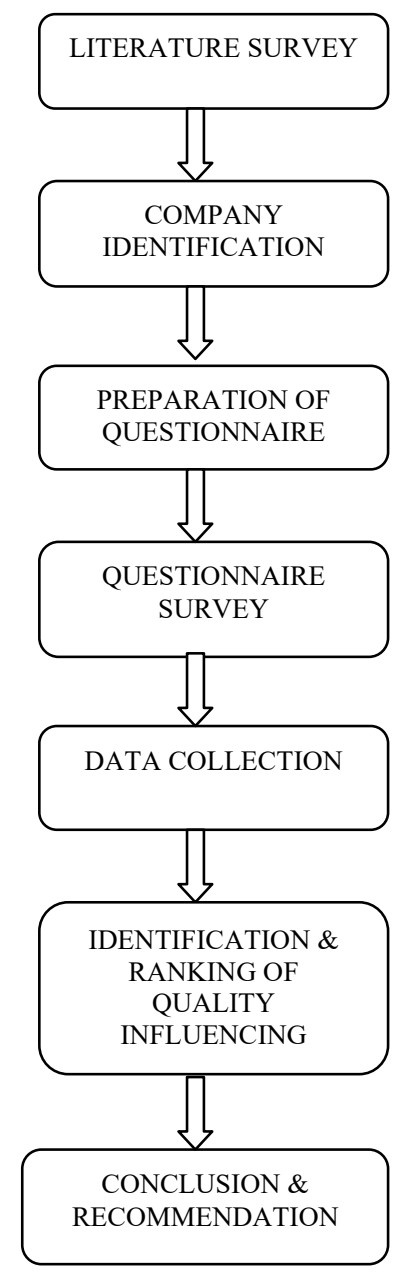

Figure 1: Research Methodology

\section{DATA ANALYSIS}

Questionnaire was designed based on this factors and it was distributed to two groups of respondents, namely contractors and consultants. The survey was conducted and the results were analyzed. 
The relative importance index method (RII) was used to determine contractors and consultants perception of the relative importance of the identified quality factors. Using this formula the major factors that affecting the quality was identified. The RII was computed as,

\section{$\mathrm{RII}=\sum \boldsymbol{w} / \mathbf{A N}$}

Where,

RII - Relative Importance Index,

$\mathrm{W}=$ weighting given to each factor by the respondents (ranging from 1 to 5 )

A $=$ highest weight (i.e. 5)

$\mathrm{N}=$ total number of respondents.

\section{FACTORS AFFECTING CONSTRUCTION QUALITY}

The factors which affecting the quality are Design, Contract, Material, Labor, Equipment, Subcontractors, Site layout, Systems, Site Staff, Execution, Financial Issues, Environment. Out of 40 questionnaires distributed 30 were returned. Perception of professionals in the construction industry was investigated. There are some correlation between the contractors and consultants in case of quality influencing factors. The factors are given in the table 1 below:

\begin{tabular}{|c|c|c|}
\hline NO & MAIN FACTOR & SUB FACTORS \\
\hline 1 & Design & $\begin{array}{l}\text { i)Completeness and consistency of design document } \\
\text { ii)Drawings are prepared in full details } \\
\text { iii)Conformance to codes and standards } \\
\text { iv)Adherence to specifications } \\
\text { v)Bill of quantity is detailed and accurate }\end{array}$ \\
\hline 2 & Contract & $\begin{array}{l}\text { i)Cooperation between parties involved in contract } \\
\text { ii)Pervious successful relations between parties } \\
\text { iii)A written contract with clear conditions } \\
\text { iv)Using a standard contract } \\
\text { v)Types of awarding system }\end{array}$ \\
\hline 3 & Material & $\begin{array}{l}\text { i)Using a comprehensive material management system } \\
\text { ii)Cooperation between contractor and material suppliers } \\
\text { iii) Availability of good quality construction materials } \\
\text { iv)Using storage and handling system } \\
\text { v)Construction materials monopoly }\end{array}$ \\
\hline 4 & Labor & $\begin{array}{l}\text { i)Labor management system } \\
\text { ii)Using labor with high experience } \\
\text { iii)Using motivation system } \\
\text { iv)Training courses for labor } \\
\text { v)Income level and wages of labor }\end{array}$ \\
\hline 5 & Equipment & $\begin{array}{l}\text { i)Availability of equipment } \\
\text { ii)Equipment management system } \\
\text { iii) Measurement of equipment productivity } \\
\text { iv)Good utilization of equipment } \\
\text { v)Equipment maintenance }\end{array}$ \\
\hline
\end{tabular}




\begin{tabular}{|c|c|c|}
\hline 6 & Sub-Contractors & $\begin{array}{l}\text { i) Company's procedures of selecting subcontractors } \\
\text { ii)High cooperation between subcontractors and general } \\
\text { contractor } \\
\text { iii)Using a system to evaluate subcontractors performance } \\
\text { iv)Good and fair subcontract conditions }\end{array}$ \\
\hline 7 & Site layout & $\begin{array}{l}\text { i)Site layout is large } \\
\text { ii)Site layout is organized well } \\
\text { iii) Site layout has storage areas for materials } \\
\text { iv)Site layout is clean }\end{array}$ \\
\hline 8 & Systems & $\begin{array}{l}\text { i)Software and computer applications } \\
\text { ii)Implement quality control and assurance system } \\
\text { iii)Using time schedule } \\
\text { iv)Using cost control system } \\
\text { v)Implementing a safety program }\end{array}$ \\
\hline 9 & Site staff & $\begin{array}{l}\text { i)Cooperation between Supervision and Contractor's staff } \\
\text { ii)Understanding of contract administration by Supervision } \\
\text { iii)Skill and experience of Supervision staff } \\
\text { iv) Skill and experience of Contractor's staff }\end{array}$ \\
\hline 10 & Execution & $\begin{array}{l}\text { i)Using integrated project execution system } \\
\text { ii)Testing for final products only } \\
\text { iii)Clear procedure for accepting performed activities } \\
\text { iv)Preparing and using shop drawings }\end{array}$ \\
\hline 11 & Financial Issues & $\begin{array}{l}\text { i)Amount of contractor's cash flow } \\
\text { ii)Non-delay of interim payments }\end{array}$ \\
\hline 12 & Environment & $\begin{array}{l}\text { i)Socio-economic environment } \\
\text { ii)Stability of Political environment }\end{array}$ \\
\hline
\end{tabular}

Table 1: Factors affecting the construction quality

\section{RESULTS AND ANALYSIS}

From the questionnaire survey the factors are identified and the ranking of factors by the degree of importance on contractors and consultants view have been done in the study and shown in the table 2 below. The goal of high quality is common to all countries. This common goal must compete with other national goals amid the massive national forces (e.g. political, economic, and social) which determine national priorities. The current study outlines the major factors influencing the construction industry. The study shows that Site Staff (both contractor and consultant staff) is found to be very important and is ranked first. The skills and experience of the contractor and supervision staff showed the highest score among the sub-factors influencing quality as shown in Table 1 . The contractor's involvement in supervision is important especially if work is subcontracted. As shown in Table 1, the contractor's procedure of selecting subcontractors and the cooperation between the subcontractors and the contractor are among the major factors influencing quality. Lack of information and overlapping activities, which are common on construction sites, may result in rework, high costs, and low quality performance. Effective coordination by the 
different teams of Site Staff may increase the effectiveness of the work and project completion. Design documents are shown to have the second priority in importance. Drawings and specifications are the two sets of documents given to the contractor that provide technical information on materials, performance of the construction facility, and quality requirements. Drawings are the only documents given to the contractor that show the design concept, size and scope of the job, number and size of materials or items, and how they are assembled into a final project.

\begin{tabular}{|c|c|c|}
\hline No & MAIN FACTOR & $\begin{array}{l}\text { RELATIVE IMPORTANCE } \\
\text { INDEX } \\
\end{array}$ \\
\hline 1 & Design & 4.62 \\
\hline 2 & Contract & 4.50 \\
\hline 3 & Material & 4.49 \\
\hline 4 & Labor & 4.20 \\
\hline 5 & Equipment & 4.11 \\
\hline 6 & Sub-Contractors & 4.08 \\
\hline 7 & Site layout & 4.03 \\
\hline 8 & Systems & 3.99 \\
\hline 9 & Site staff & 3.91 \\
\hline 10 & Execution & 3.78 \\
\hline 11 & Financial Issues & 3.77 \\
\hline 12 & Environment & 3.73 \\
\hline
\end{tabular}

VII. CONCLUSION AND RECCOMMENDATIONS

This study shows that among the 12 main factors and 60 sub-factors, Site Staff, Design, Financial Issues, Subcontractors, Material, Labors, Systems, Environment, Contract, and Execution are the main factors influencing quality. The analysis of results showed that these 10 main factors contribute $74 \%$ of the total weight of all factors. The political environment affected the quality of building construction projects. The interrelationship of environment factor with many other factors influenced the ranking of these factors. Improvements in the aspect of 
work related to these factors should make it possible progressively to improve quality in construction projects. The results showed that there is an obvious need for extensive studies on how to improve quality on both national and a company level. The present study is an essential first step towards highlighting the major issues that need attention to improve the quality of building construction projects. More efforts is still needed to investigate ways to formulate management systems (policies and procedures) to handle each factor individually.

\section{REFERENCES}

[1] Arditi, D. \& Gunaydin, H. M. (1998) Factors that affect process quality in the life cycle of building projects, ASCE Journal of Construction Engineering and Management, 124(3), pp. 194-203.

[2] Atkinson, R. (1999). Project Management: Cost, Time and Quality, Two Best Guessesand a Phenomenon, It's Time to Accept Other Success Criteria. International Journal of Project Management 17 (6): 337-342.

[3] Barnes, M. (1987) Construction Project Management, Seminar on 'Construction Project Management', 21-22 October, London, UK.

[4] Bubshait, A. A. \& Al-Atiq, T. H. (1999) ISO 9000 quality standards in construction, ASCE Journal of Management in Engineering, 15(6), pp. 41-46.

[5] Chua, D. K. H. et al. (1999) Critical success factors for different project objectives, ASCE Journal of Construction Engineering and Management, 125(3), pp. 142-150.

[6] Collins, Jr., F. C. (1996) Quality: The Ball in your Court (New Delhi, India: Tata McGraw-Hill). Drucker, P. F. (1969) Concept of the Corporation (Boston, MA: Beacon Press).

[7] Davis, K., Ledbetter, W.B., and Burati, J. (1989),’Measuring Design andConstruction Quality Costs” Journal of Construction Engineering and Management, Vol.115, No.3.

[8] Enshassi, A., Mohamed, S. and, Abushaban, S., (2009). Factors Affecting the Performance of Construction Projects in the Gaza Strip, Journal of Civil Engineering and Management, Vol. 11, No. 2, PP. 1-1

[9] Kumaraswamy, M.M. and Thorpe, A. (1999). Systematizing Construction Project Evaluations. Journal of Management in Engineering 12 (1): 34-39.

[10] Ledbetter, W. B. (1994) Quality Performance on successful project, ASCE Journal of Construction Engineering and Management, 120(1), pp. 34-46.

[11] Love, P. E. D. \& Smith, J. (2003) Benchmarking, benchaction, and benchlearning: rework mitigation in projects, ASCE Journal of Management in Engineering, 19(4), pp. 147-159.

[12] Mbugua, L.M., Harris, P., Holt, G.D., and Olomolaiye, P.O. (1999). A Framework for Determining Critical Success Factors Influencing Construction Business Performance. In: Hughes, W. (Ed.) Proceedings. $15^{\text {Th }}$ Annual ARCOM Conference. September 5-7, Reading: ARCOM. 1:255-264.

[13] Pheng, L. S. (2004) Implementing total quality management in construction firms, ASCE Journal of Management in Engineering. 